\title{
茶室における人が認知する平面領域と心理評価に関する研究 STUDY ON RECOGNIZED SPACE ON PLANE SURFACE AND PSYCHOLOGICAL EVALUATION IN THE TEA CEREMONY ROOM
}

\author{
子 浦 中*1, 鈴木 弘 樹*2
}

Ataru SHIO and Hiroki SUZUKI

\begin{abstract}
This study is aimed to clarify the characteristics of changes and psychological evaluation in guest's personal space and solidarity spaces during the tea ceremony.

1. The personal space hardly change, while the other's personal spaces increase. The solidarity space increases in the middle and decreases after exiting the tea ceremony.

2. The most influential factor of spatial recognition is "delivery of the tea and desserts."

3. The common psychological factors that change simultaneously among thick tea and thin tea, are spatial factor, variability factor, richness factor and impression factor, while comfortable factor, tension factor and peculiarity factor change differently.
\end{abstract}

Keywords:Tea ceremony room,Spatial Recognition,Region,Psychological Evaluation,Thick Tea,Thin Tea

茶室，空間認知，領域，心理評価，濃茶，薄茶

\section{1. 研究の目的とその背景}

茶室 $^{\text {注1) }}$ とは、茶湯 ${ }^{\text {注2) }}$ に使うための建物である。千利休 ${ }^{\text {注3) }}$ 以前、 侘び茶の祖と言われる村田珠光 ${ }^{\text {i住 }}$ の頃からすでに 6 畳、 4 畳半といっ た茶室が存在した。4 䪶半は茶室の基本的な間取りとして位置付けら れていた。その後、千利休によって安土・桃山時代以降の 4 畳半以 下の草庵茶室 ${ }^{\text {济) }}$ が確立された。

茶室で行われる茶事 ${ }^{\text {注6) }}$ の一般的な進め方 (Fig. 1) は、亭主が客に 案内状を出すことからはじまる。茶事当日、寄付に集まり、迎付、席入、 初座炭点前、懐石、中立、濃茶、薄茶、退席にいたるまで約 4 時間 ほどをかけて行う (Fig. 2)。一方、長時間行われる茶事に使う狭い茶 室は、人とのコミュニケーションをつなぐ世界でも類を見ない建築 空間である。4 畳半以下の茶室に最大 7 名ほどが座る。茶事の中で亨 主、客のコミュニケーションは、時間の経過とともにその空間内で 親密度が増す。これまで行われてきたパーソナルスペース（以下 PS） の研究は、身体の周辺で他人が近づいた場合、「気づまりな感じ」や、 近すぎて「離れたくなる感じ」がするような領域として実測されて いる。しかし、茶室内において茶事の流れとともにPS は親密になる と考えられる。本研究ではPS の従来の研究を支持し、PS を『個人の 領域』と定義する。PS は、人間が他の人間との間にある種の空間・ 距離を保ち、他人を入れないように個々があたかも目に見えないバ ブル（泡）に包まれているかのように、人の体を取り囲む領域であ るといわれている。そのため、個人の領域は 3 次元であるが、茶室
内において客は床面 (畳) に座り、茶碗や菓子器などの茶事に必要 なものを床面に置く茶動作が多く、亭主及び客は常に床面を意識し ていることから、本研究は平面 (床面) の領域に着目し、個人が自 分の平面と意識する領域、他の客と連帯している領域を研究対象と する。よって本研究での領域は『平面領域』（以下領域と略し、平面 領域を指す）を意味し定義する。次に空間認知は外界の認知において、 対象の広がり、奥行、対象間の位置関係、自己と対象との距離、方 向などの空間的特性を認知することであるが、従来の研究を参考に すると茶室内における空間認知とは、茶室内において茶事の流れと ともに変化する個人の頭の中にある個人や亭主、他の客と連帯して いる領域のイメージを認知することと考えられる。本研究ではこれま でのPS と空間認知の研究を参考にしながら、茶室内の茶事を通して 客個人が個人の領域、他人の領域、個人や亭主、他の客の連帯した 領域が生まれ、それらが茶事の流れとともにどのように変化してい くか変化の特徵を明らかにすることを目的する。本研究で得られた 結果は、今後茶室内で行う茶事において個人の領域がすぐ離れたい と感じないことを実証し、茶室のあり方を理解する知見になると考 える。

\section{2. 既往論文と本研究の位置づけ}

これまでの茶室建築における研究は、多岐にわたる調査がされて いる。既往の研究としては以下のものが挙げられる。多変量解析に

\footnotetext{
*1 千葉大学大学院工学研究科 博士後期課程 - 修士 (工学) Grad. Student, Dept. of Architecture, Faculty of Science and Engineering, Chiba Univ.

*2 千葉大学大学院工学研究科 准教授・博士 (工学 $)$ 
よる茶室の意匠論 ${ }^{122}$ 、空間論、建築家堀口捨巳の茶室の建築思想に 関するもの ${ }^{3445)}$ 、茶庭に関するもの、特定の茶室に関するもの ${ }^{6)}$ 、茶 道具に関するもの ${ }^{7)}$ や各論に関する歴史の研究を行っている。小木曽、 杉本 ${ }^{89)}$ らは、茶室の窓の位置から設計者の意図する採光を明らかに

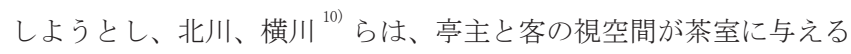
影響から設計意図を研究した。中村、岡崎、鈴木 ${ }^{11}$ らは、露地研究 において歩行者の注視行動の観点から飛石の影響を捉え、佐藤、新 宮 $^{12}$ らは、茶室の意匠をコンポジション認識の手法を使って数理的 な解釈をし、後藤、瀬口 ${ }^{13) 14)}$ らは、茶室の写しにおいて建築的構成 要素の継承実態を把握しようとした。水谷、北川 ${ }^{15)}$ らは、茶室構成 が視空間に与える影響を究明し、その後、視深度からみる茶室の内

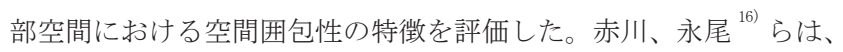
茶事の中で亭主と客の動線と茶室の相関関係を解明しようとし、船 越、積田 ${ }^{17)}$ らは、心理量、物理量、相関分析を茶室の適応すること により空間意識と空間構成要素との適量的関係を考察した。また、 これまでの PS における既往の研究は、以下のものが挙げられる。橋 本、西出 ${ }^{18)}$ らは、心理的領域の大きさと空間の対応関係の特性を明 らかにしようとし、荻谷、西出 ${ }^{19)}$ らは、建築情景と人間情景を同じ

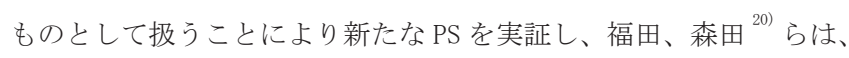
PS に他人の侵入がもたらす心理的空間や生理的圧迫の影響を研究し、 羽生、林田 ${ }^{21)}$ らは、座位者の体の向き、視点に対する高さ方向への 空間操作を考察した。本研究ではこれまでの茶室建築の研究とは異 なり、PS の研究を参考にしつつ、茶室内において茶事を通して領域 の認知や意識の感じ方の変化や特徵を明らかにする。上記の視点か ら茶室における茶事の茶動作に伴う個人の領域、他人の領域、個人 や亭主、他の客の連帯した領域の認知、心理量を捉える研究は、こ れまで事例が認められない。

\section{3. 本研究における個人領域、連帯領域の定義}

本研究では、PSの定義を支持しつつ、茶室という限定された空間 において他人との空間や距離を保ちたくても保てない状況で、個人 の領域が発生すると同時に茶事に参加した人々に連帯感が生まれ、 それら同士が共有する領域である連帯する領域が存在すると考えら れる。また、本研究では、個人の領域と茶事に参加した他人の領域、 茶事に参加した人々の連帯する領域を同時に捉えて分析をする。そ のため同じ茶室内において個人が自分の領域と思って意識する心理 的な床面に広がる (以下略) 領域を『個人領域』、個人が連座する客 の領域と意識したと思われる領域を『他人個人領域』、個人や亭主、 他の客の連帯した領域と意識したと思われる領域を『連帯領域』と 定義し、それらは茶事の一部である濃茶、薄茶 (Fig. 2) の各進行ととも に関連を持ちながら変化すると仮定して研究を進める。また本研究は、 これまで研究されている空間認知を参考にしつつ、個人領域、他人 個人領域、連帯領域を認知する総体を『領域認知』と定義して扱う。

\section{4. 本研究の流れ}

本研究では、Fig. 3 で示す通り茶事を通して個人領域、他人個人領 域、連帯領域が生まれ、領域認知や空間の感じ方がどのように変化 していくかの特徴を明らかにする。今回は、お茶の種類や飲み方な どが異なる濃茶と薄茶に着目し実地調查を行う。調查から得られた数 值による客観的なデータを分析し、関係性を考察する。

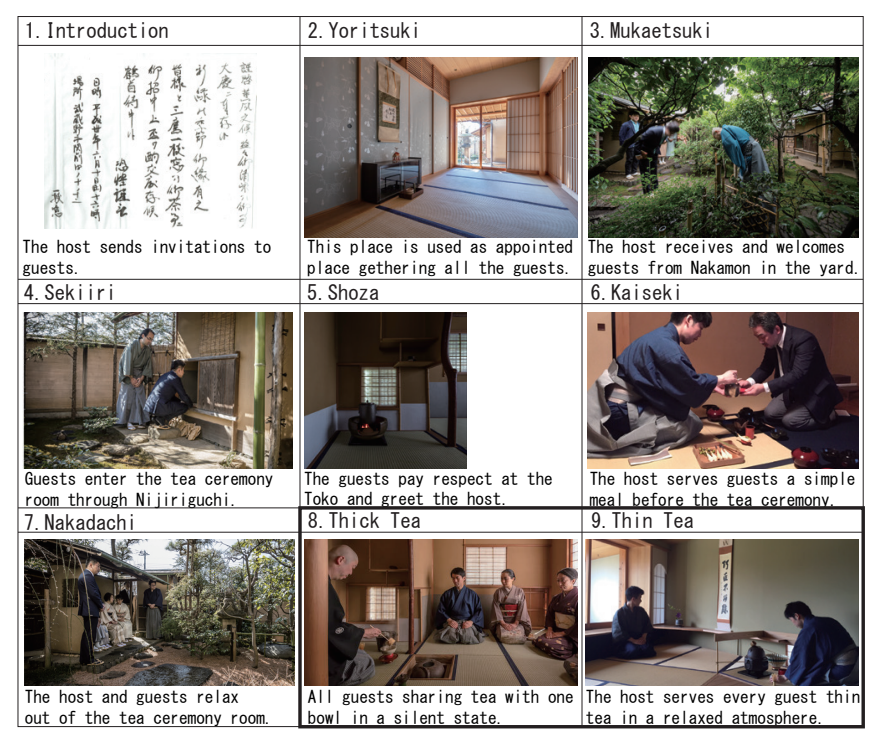

Fig. 1 Main procedures in the tea ceremony

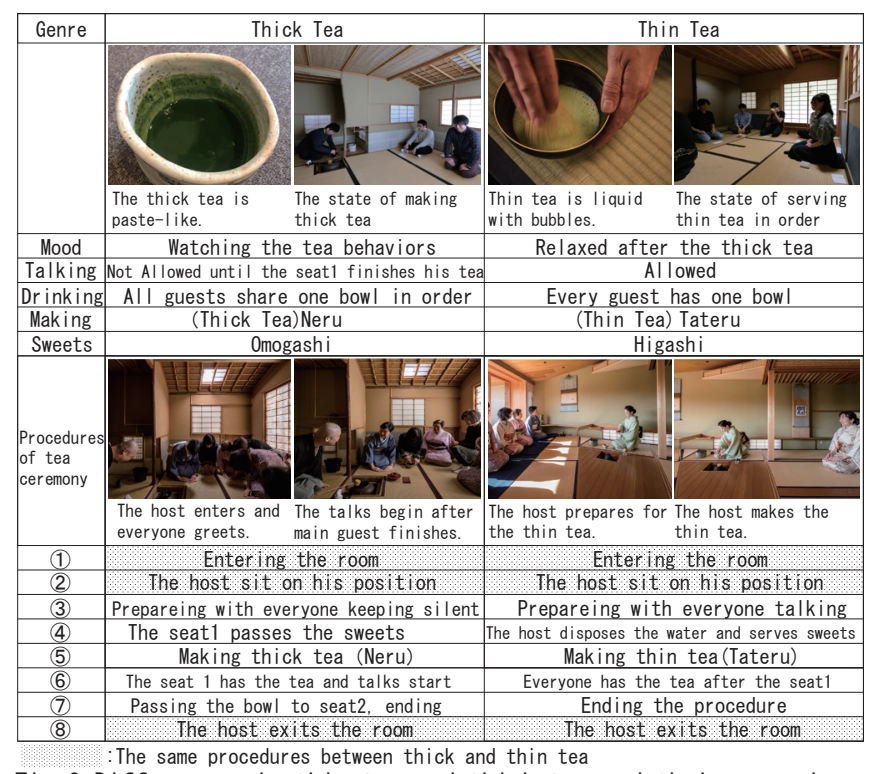

Fig. 2 Differences in thin tea and thick tea and their procedures

\begin{tabular}{|c|c|}
\hline Field Survey & Focused on thick tea and thin tea, surveys were conducted by the steps in Fig. 2 \\
\hline Contents $L^{T}$ & 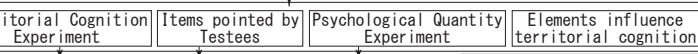 \\
\hline Analysis $E_{-A}^{A}$ & 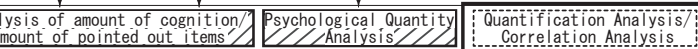 \\
\hline
\end{tabular}

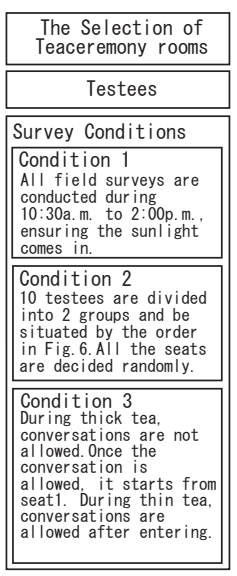

There are 11 examinable tea ceremony rooms seleceted, which are bigger
than 3 tatatami mats and al low 5 guests entry besides the host (Fig. 4 ). To el iminate prejudice and to value the intuition to the research, 10
architectural students who don t have any exper ience on tea ceremony or have been to appointed tea ceremony rooms are chosen every time. Survey Method So Method Psychylogical experiment
To clarify the psychological infl luenced made by tea ceremony at the enter ing and exiting point, the $S \mathrm{SO}$ method psychological exper iment
is conducted. The enter ing point is before the host enters the tea

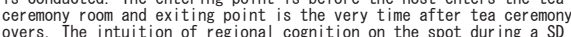
method psychological exper iment is very important so we choose not to interrupt the flow to insert an experiment in the middle. Regional Cognition Experiment To clarify the tendencies of changes from personal space, other's personal space and sol idar ity space, the regional cognition exper iment is conducted. After the SD method psychological exper iment of exiting point is done, testees are asked to leave
the place, recall the situations and fill in the cognition map. Pointing Method Experiment

The pointing method experiment is conducted to show the items that The pointing method exper iment is conducted to show the items that
inf luenced the evaluations of tea ceremony and space. Testees are asked to write down the items that influenced the eval uation of tea ceremony room and space.

Fig. 4 The Flow of Surveys 


\section{5. 調査の概要}

\section{1 実験場所 · 被験者}

本研究で行う調查 $^{\text {注7) }}$ をig. 4 に示した。調查場所は、数人の領 域の関係を明らかにするための適切な大きさとして、千利休によっ て確立されたと言われる 4 疊半以下の広さを持つ草庵風の小間の茶 室に着目した。調查に使用した茶室は、広間と小間で予備実験を行 い領域の認知に変化が見られた小間を対象とし、調查が可能で亭主 を除いて 5 人が入室できることを調査条件に 3 畳以上の小間の茶室 を 11 箇所選定した (Fig. 5)。これらの茶室をK-Tei、K-An、T-Tei、 T-Room、S-An、M-House は 4 畳半の同一の型（以下 4 畳半型）、

S-Tei、Y-Tei は 4 畳半台目の同一の型（以下 4 畳半台目型）の茶室、 それ以外の茶室 (以下その他) として分類する。被験者 ${ }^{\text {ì) }}$ は、調査 毎に 10 名で、過去に調查に使用する茶室を訪れたことがない建築を 専攻する学生である。

\section{2 調査条件 $\cdot$ 調查方法 $\cdot$ 調査手順}

実地調查は以下の条件、方法で行う

条件 1 : 実地調査を行う時間は、全ての調査において、茶室内に自 然光が入る午前 10 時半から午後 2 時にかけて統一して行う。

条件 2 : 茶室内において客が座る位置を客座と定義し、亭主に近い位 置から客座 1 として、大きさの異なる茶室で半畳に 1 人ずつ座ることを 目安とする条件 ${ }^{\text {主9) }}$ として客座 5 まで座ることとする。1 回の実地調查は、 被験者が客座 1 ～ 5 に座ってから、亭主が茶室に入室し、茶動作を行 い退室するまでとする。各茶室それぞれ 10 名の被験者を 2 組に分け、 Fig. 5 のように客座に座った。調査毎の座る位置は毎回くじ引きを行 う。

条件 3 : 茶事の流れに合わせるため濃茶と薄茶の順でお茶の種類、 飲み方の異なる茶動作を体験してもらう。調査中、濃茶では客座 1 がお茶を飲み終わるまで会話は行わず、会話を始める場合は客座 1 から始める。薄茶では入室時から会話をしても良い。 以上の条件で 3 つの調查を行う。

調查は以下の方法、手順で行った。(Fig. 6)

調査 1 : 茶事や空間が客にどのような意識を与えるかを明かにするた めの SD 法による心理実験

入室時、退室時で茶室内においての茶動作を通して客の心理に与 える影響を明らかにするために、茶室内において入室時、退室時に SD 法心理実験を行った。本研究の心理実験は、空間を体験した際に 受けた感覚を数量化することが可能な 7 段階評定尺度の SD 法心理実 験注 10$)$ とした。SD 法心理実験は入室時は亭主が入室する前に、退室 時は亭主が退室後、被験者にそれぞれの心理変化を Fig. 7 左の調査 用紙に記入してもらった。本研究の心理評価の測定に使用寸る形容 詞対は、茶室の空間を分析するにふさわしいと思われる形容詞対を 過去の研究も参考に考えられる限りあげ、調查員 3 名による KJ 法的 手法で整理し、茶室の空間を表現するものとしてふさわしいと考え る 34 形容詞対を予備調查で確認し選定した。本研究では、SD 法心理 実験は入室時は亭主入室前に、退室時は茶事終了後すぐに行い中間 時は行わなかった。その理由は、SD 法心理実験はその場において直 感的に空間の意識を記入してもらう実験であるとからことから、茶 事の一連の流れを重要視し、実験を挟み茶事を中断することを避け るためである。

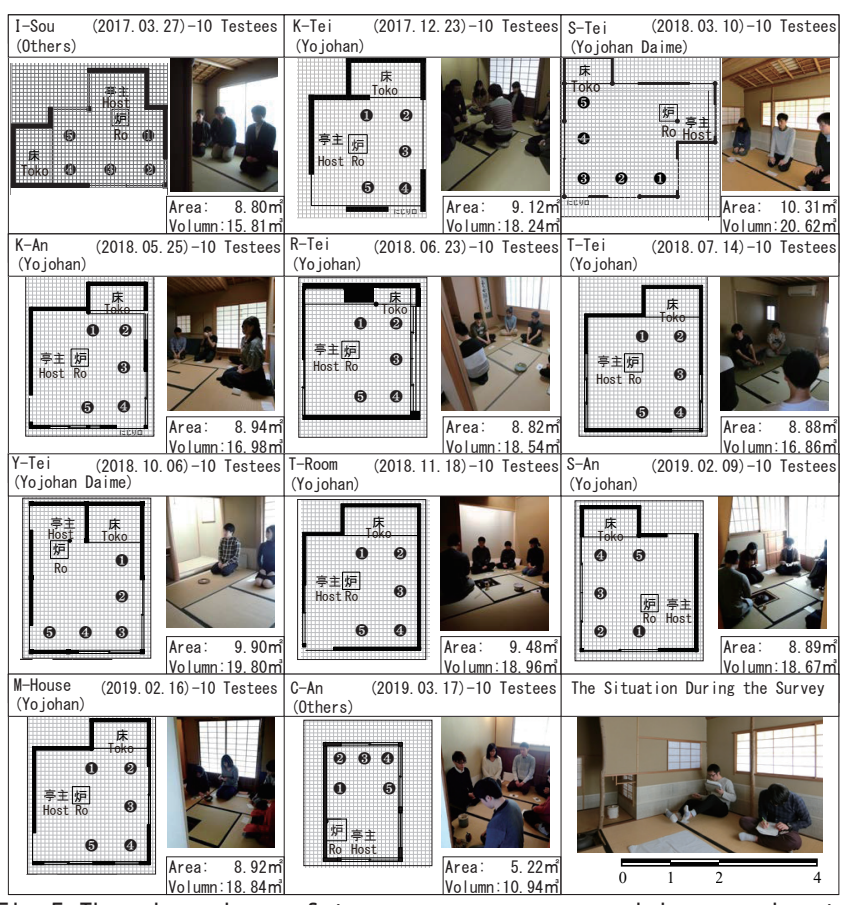

Fig. 5 The plan views of tea ceremony room used in experiments and the state of the experiments

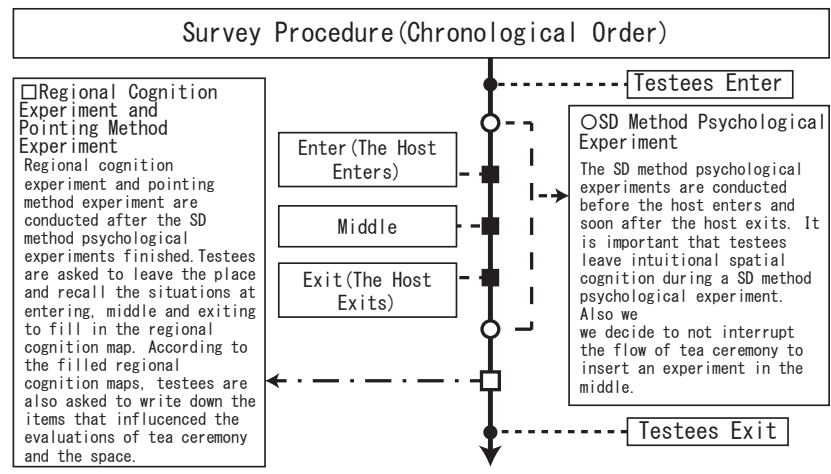

Fig. 6 Experimental Procedure

The changes of personal space and spatial evaluation by tea behaviors I. Please circle the appropriete levels of the adjectives

Thin Tea Seat No. Name

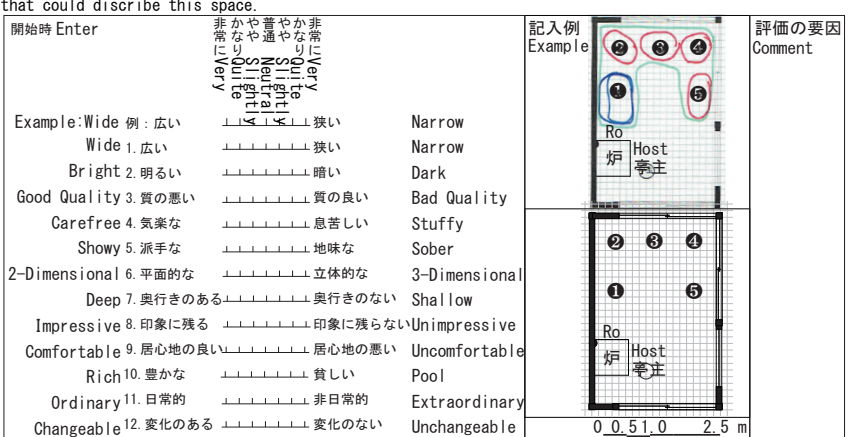

Fig. 7 A part of survey forms used in the research (Example)

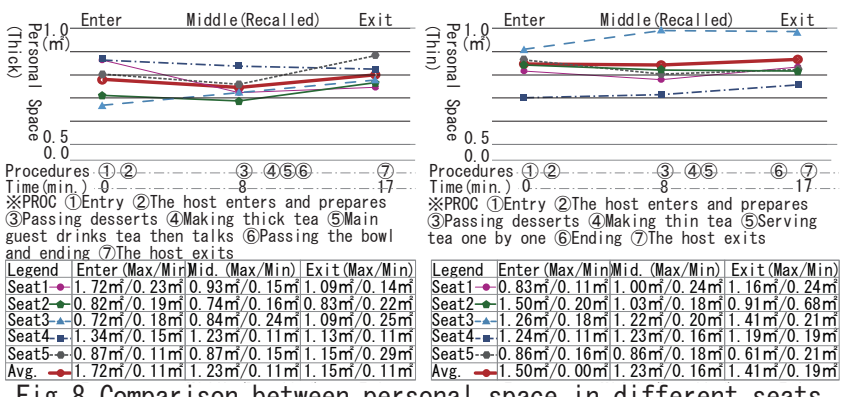

Fig 8 Comparison 
調查 2 : 個人領域、他人個人領域、連帯領域の変化量、領域認知の 傾向を知るための領域認知実験

入室時、中間時、退室時で茶室内における茶動作が客の領域の認 知に与える影響を明らかにするために、被験者に Fig. 7 の調査用紙 の記入例を参照し個人領域を青、他人個人領域を赤、連帯領域を緑 で平面図に記入する領域の認知図 (以下、領域認知図 ${ }^{\text {湆 }}{ }^{11}$ ) を作成し てもらった。領域認知図の作成は、退室時の SD 心理実験終了直後に その場を離れ、入室時、中間時、退室時の状況を思い出して記入し てもらう形とした。

調査 3 : 茶事や空間を評価することに影響を及ぼした要素 (以下空 間要素 ) の指摘法実験

入室時、中間時、退室時で茶室内における領域認知図を利用し、 茶事や空間を評価することに影響を及ぼした要素をFig. 7 の評価の 要因欄に被験者に記入、指摘してもらった。

\section{6. 濃茶と薄茶における領域認知の比較}

Fig. 8, 9, 10 は、濃茶と薄茶の前述の実験で被験者に Fig. 7 の調 查用紙に個人領域を青、他人個人領域を赤、連帯領域を緑で記入し てもらった領域認知図から、それぞれの領域の面積をすべて測った データと空間要素を被験者に記述で指摘してもらった結果のデータ である。すべての領域認知図に記入してもらった個人領域、他人個 人領域、連帯領域の面積を測り客座毎に平均值を出し、入室時、中 間時、退室時にかけての客座別の個人領域、他人個人領域、連帯空 間の面積の変化をグラフ化した。Fig. 8, 9, 10 のグラフは濃茶、薄茶 毎の各領域における入室時、中間時、退室時にかけての客座別の平 均面積変化を示している。グラフ下には、入室時から退室時にかけ ての茶事の流れを示した。図下の表は客座毎の各領域における入室 時、中間時、退室時の最大面積、最小面積である。Fig. 11, 12 は被験 者に Fig. 5 で示寸茶室での調查時に、Fig. 7 の調查用紙に個人領域 を青、他人個人領域を赤、連帯領域を緑で記入してもらった、濃茶、 薄茶における茶室の型別の客座毎の特徵的な領域認知図の一部であ る。領域認知図横には、そこに示している茶室の型別における客座 毎の各領域認知図の入室時から中間時、中間時から退室時における 平均の面積変化量を示している。濃茶、薄茶の客座全体に共通する 個人領域の入室時から退室時における面積変化の特徴について分析 すると (Fig. 8)、入室時から退室時にかけて被験者に記入してもらっ た領域認知図の個人領域の面積平均值 (以下、領域值とし、以下略) は、濃茶 $0.16 \mathrm{~m}^{2}$ 薄茶 $0.19 \mathrm{~m}^{2}$ とほとんど変化はない。客座毎の領域 認知図の入室時から退室時の変化についてみていくと、個人領域は 入室時、中間時、退室時のどこかのタイミングで客座位置の前に炉 や、横に空いている空間がある場合は、濃茶、薄茶に関係なく個人 領域が広がることがわかる（Fig. 11,12）。被験者に指摘してもらった 空間要素に、隣に被験者がいない場合は個人領域が広く感じたとい う指摘があるが、濃茶客座 1 のような場合は中間に亭主が存在する ため個人領域が広がらないと考えられ、客座 5 は濃茶、薄茶ともに 左側に被験者がいないため個人領域が広がると考えられる。このよ うに茶動作の違いに関係なく客座位置とその周辺環境が個人領域の 領域認知に影響を与えている事が明らかになった。濃茶、薄茶に共 通する他人個人領域の領域值の特徵について分析すると、入室時か ら退室時にかけて濃茶 $0.49 \mathrm{~m}^{2}$ 薄茶 $0.47 \mathrm{~m}^{2}$ 大きくなる (Fig. 9)。次に
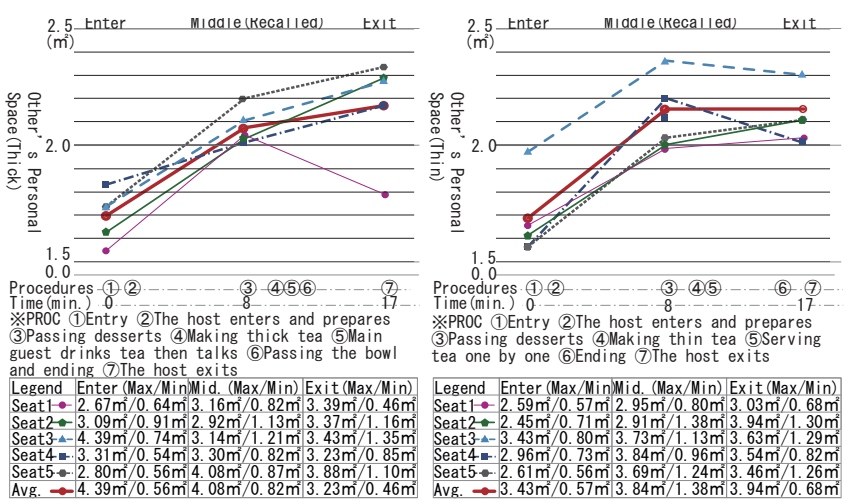

Fig. 9 Comparison between other's personal space in different seats
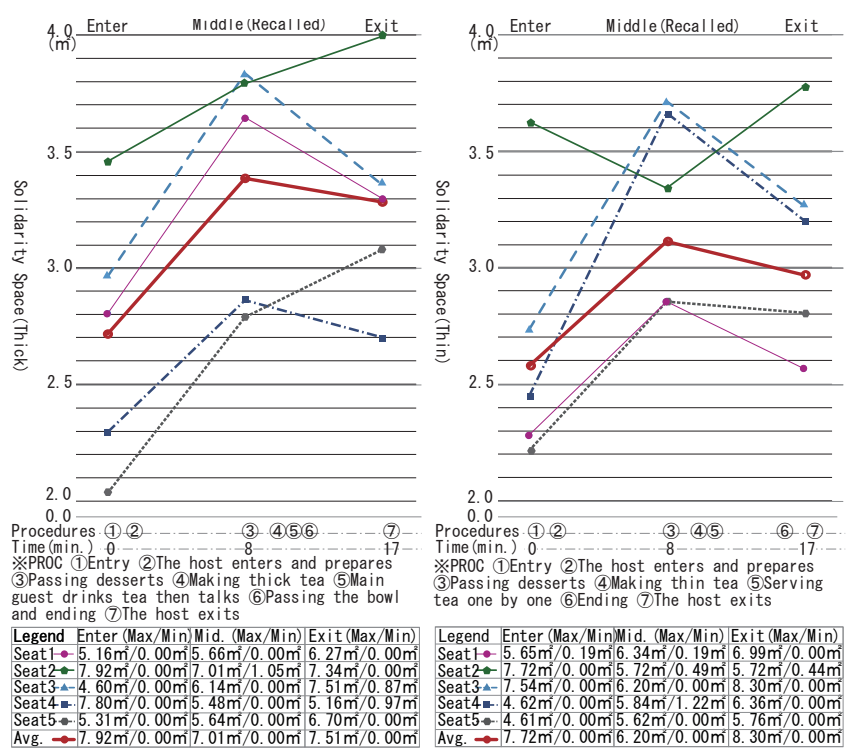

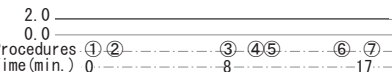
※PROC (1)Entry (2)The host enters and prepares
3 Passing desserts 4 Making thin tea 5 SServing 3Passing desserts (4) Making thin tea 5 S Servits
tea one by one 6 Ending 7 The host exits Legend
Enter (Max/Min/Mid. (Max/Min) Exit (Max/Min)

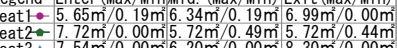

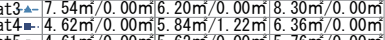

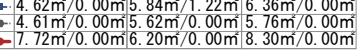

Fig. 10 Comparison between solidarity space in different seats

他人個人領域の領域值を客座毎にみていくと、全ての客座の他人個 人領域の領域值は入室時から退室時にかけて $0.33 \sim 0.65 \mathrm{~m}^{2}$ 大きく なり、客座 1 を除く客座は、中間時から退室時にかけての変化が入 室時から退室時にかけての変化より緩やかになる傾向にあるが、終 始減少せず増加する (Fig. 9)。濃茶の連帯領域の領域值の特徵につい て分析すると (Fig. 10)、連帯領域の領域值は入室時から中間時にか けて $0.66 \mathrm{~m}^{2}$ 大きくなり、退室時にかけて $0.10 \mathrm{~m}^{2}$ 小さくなり、入室 時から退室時にかけて $0.56 \mathrm{~m}^{2}$ 大きくなる。これは、濃茶特有の 1 碗 のお茶を客座 1 から 5 まで全員で回し飲夕寸る茶動作が影響してい ると考えられる。薄茶の連帯領域の領域值の特徵について分析する と (Fig. 10)、連帯領域の領域値は入室時から中間時にかけて 0.70 $\mathrm{m}^{2}$ 大きくなり、退室時にかけて $0.18 \mathrm{~m}^{2}$ 小さくなり、入室時から退室 時にかけて $0.51 \mathrm{~m}^{2}$ 大きくなる。領域値の有意について、濃茶、薄茶 ともに他人個人領域の入室時と中間時、入室時と退室時に、 $5 \%$ 水準 で有意が確認された。有意が確認されたと濃茶、薄茶と他人個人領 域の入室時と中間時、入室時と退室時の領域值についてみていくと、 濃茶、薄茶の入室時と退室時の領域值は、濃茶 $0.49 \mathrm{~m}^{2}$ 、有意差 $0.80 \%$ 、 薄茶 $0.47 \mathrm{~m}^{2} 0.80 \%$ とほとんど変わらないが、入室時と中間時の領域 值は、濃茶 $0.39 \mathrm{~m}^{2}$ 有意差 $3.2 \%$ 、薄茶 $0.49 \mathrm{~m}^{2} 0.80 \%$ と濃茶で差が出 る。このことから、他人個人領域の入室時と中間時において、客が 茶事を通して濃茶と薄茶の領域認知に違いが生まれ、領域值に差が 


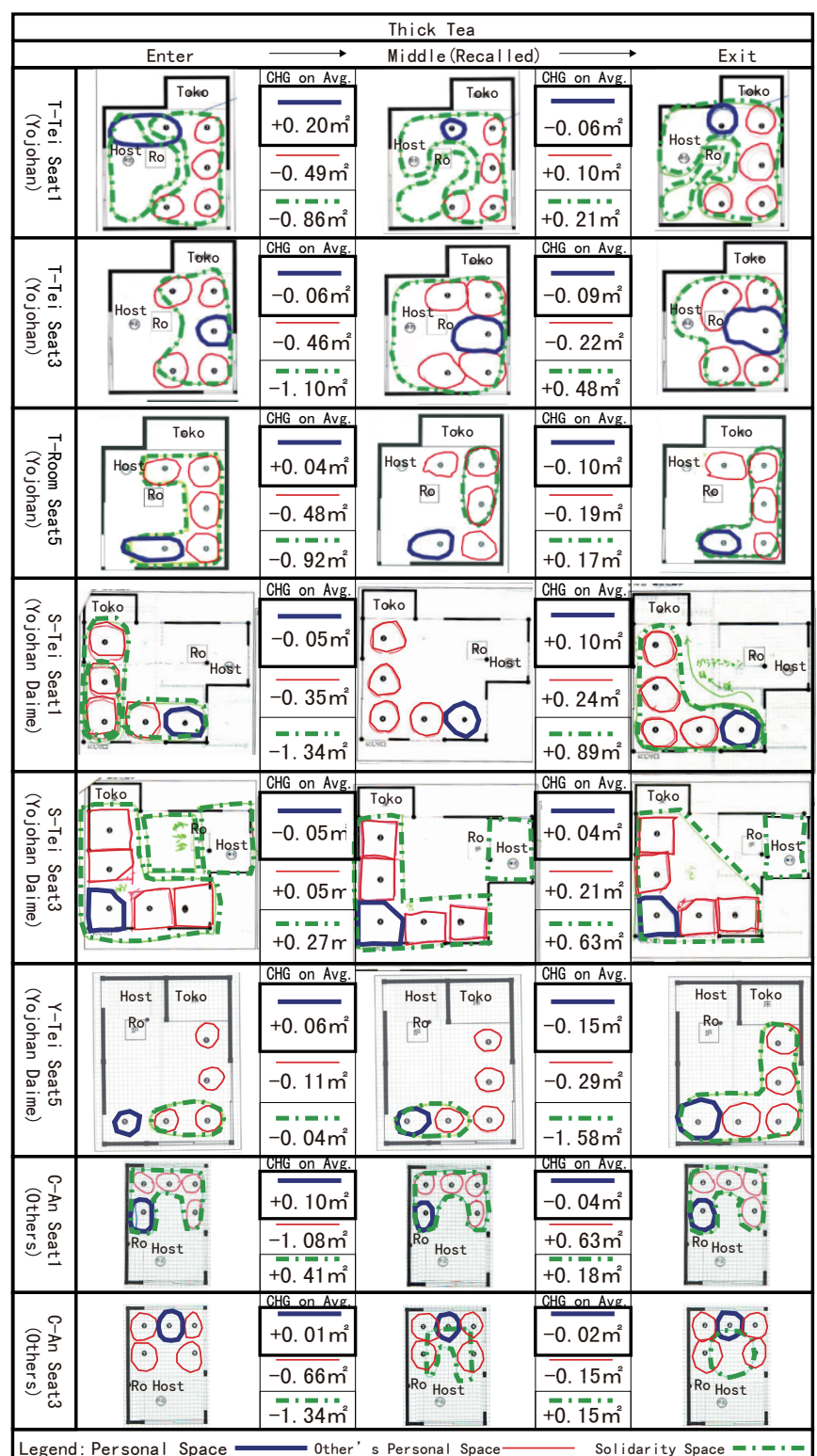

Fig. 11 Distinct regional recognition diagram observed by the differences of types of tea ceremony rooms in thick tea (Partial)



Fig. 13 Comparison between personal space, other' $s$ personal space and solidarity space in different types of tea ceremony rooms

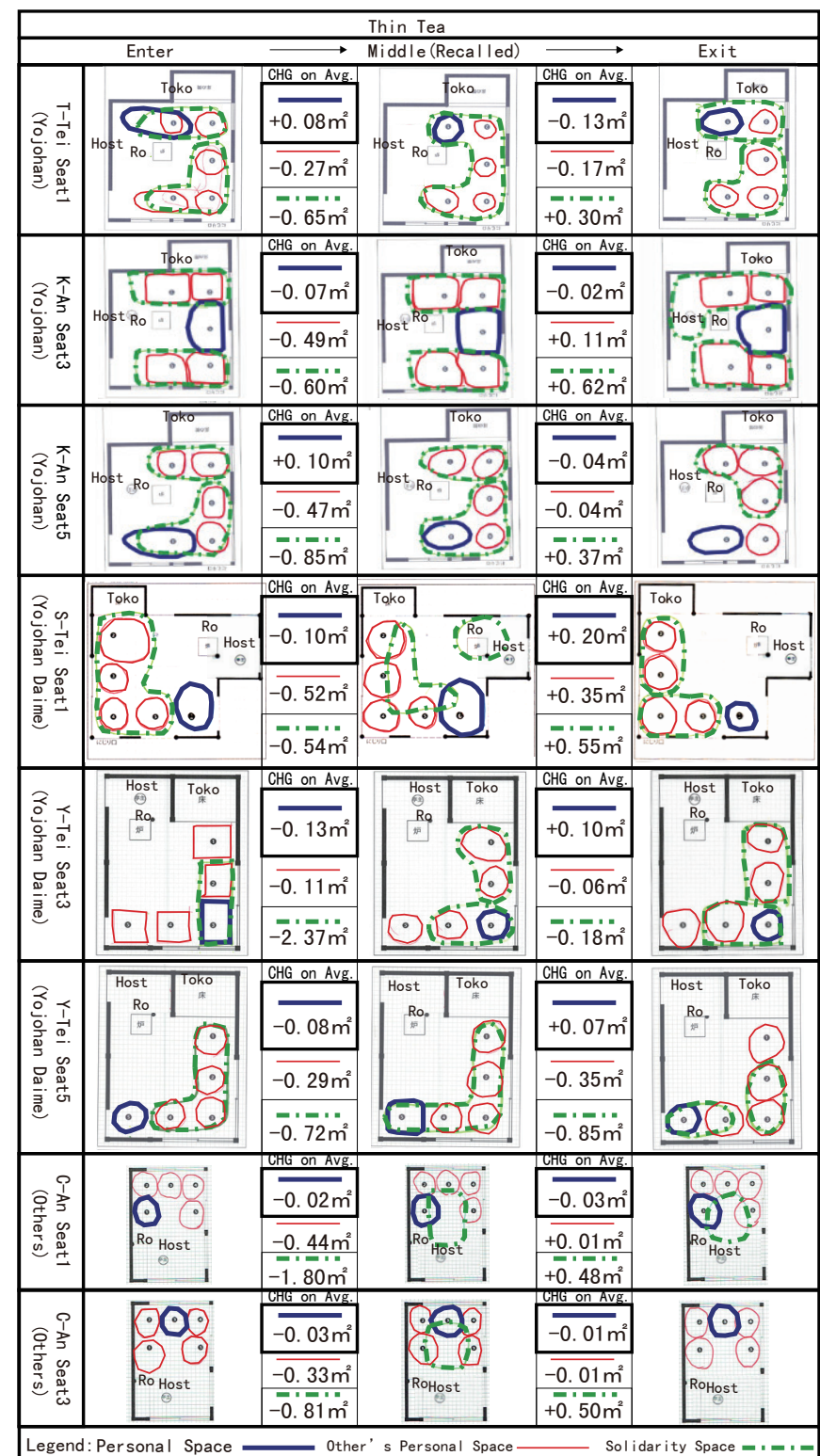

Fig. 12 Distinct regional recognition diagram observed by the differences of types of tea ceremony rooms in thin tea (Partial)

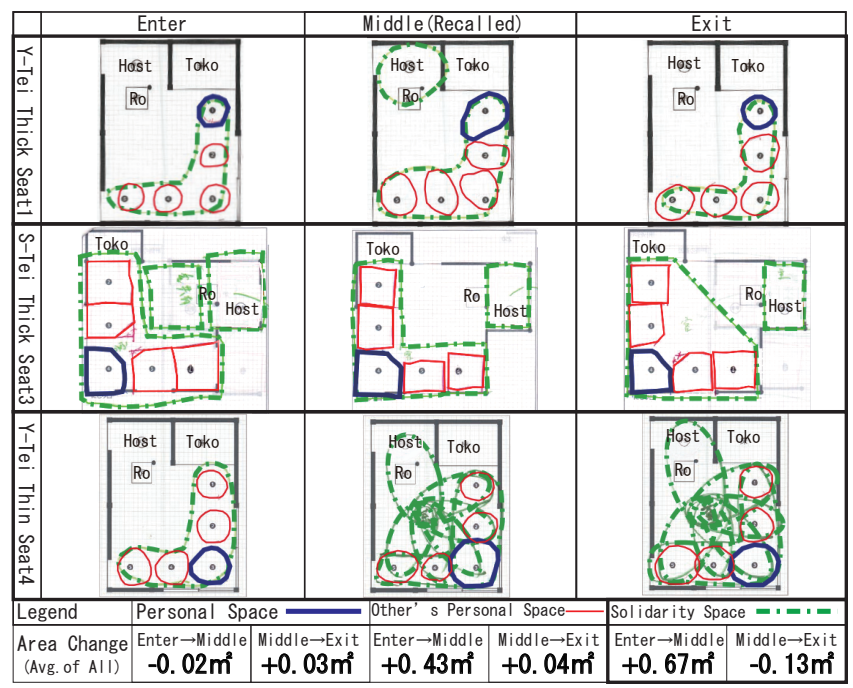

Fig. 14 Distinct regional recognition diagram observed in thick tea and thin tea 
出ることがわかる。濃茶と薄茶の茶室の型の違いについて領域認知 図の個人領域、連帯領域を比較すると (Fig. 11, 12)、濃茶、薄茶と もに個人領域は茶室の型で違いが出るが、連帯領域は茶室の型の違 いによる大きな差はないことがわかる。濃茶の 4 畳半型と 4 畕半台 目型の特徵的な領域認知図を比較すると（Fig. 11）、個人領域につい て 4 畳半型の客座 $1,3,5$ は、隣の空いている空間に広がるが、 4 盢半 台目型の客座 $1,3,5$ 、その他 1,3 は、隣に空いている空間がないため 広がることが出来ない。連帯領域は、 4 畳半型と 4 畳半台目型、その 他全てに共通して退室時に客全員がつながることがわかる。個人領 域については、 4 畳半型と 4 畳半台目型、その他全てにおいて茶室の 型の違いが出ることがわかる。薄茶の 4 畳半型と 4 睤半台目型、そ の他の特徴的な領域認知図を比較すると (Fig. 12)、個人領域につい て 4 畳半型の客座 $1,3,5$ は、濃茶と同じように個人領域について 4 冨半型の客座 $1,3,5$ は、隣の空いている空間に広がるが、 4 畳半台目 型の客座 $1,3,5$ 、その他 1,3 は、隣に空いている空間がないため広が ることが出来ない。連帯領域は、 4 畳半型と 4 畳半台目型とも共通し てどのタイミングでも会話している隣同士の人とつながり、茶室が 狭いその他は客全体とつながると考えられる。濃茶と薄茶の同じ型 における領域認知図の連帯領域を比較すると、濃茶は 4 畳半型、 4 畳 半台目型、その他の全てにおいて入室時から退室時まで連帯領域が 客全体でつながっているものが多いのに対して、薄茶は 4 畳半型、4 畳半台目型共に隣同士で連帯領域がつながるものが多い。その他は 中間時に客全体でつながっている。これは、濃茶の入室時は会話が 出来ないため茶室の中で客同士が無言で座っている、中間時は客同 士でお菓子を取り回す、退室時はお茶を回し飲みするというそれぞ れ違う茶動作があるためであると考えられる。それに対して薄茶は 入室時から会話が出来るため、会話している人と連帯領域がつなが り、中間時はほとんどの茶室において客全員で連帯領域がつながっ ていることから、客同士でお菓子を取り回寸茶動作が連帯領域をつ なげる要因になっていると考えられ、退室時は客全員ではなく会話 している客同士がつながっていると考えられる。その他は 4 睤半型、 4 畺半台目型に比べ茶室が狭いため、隣同士というよりも客全体でつ ながると考えられる。連帯領域がつながる要因は、濃茶は入室時か ら退室時を通して茶動作、薄茶は会話であると考えられる。Fig. 13 は、Fig. 8, 9, 10 と同様、被験者が領域認知図に記入した各領域の面 積を測り茶室の型別に平均值を出し、入室時から退室時にかけての 茶室の型別の各領域值の変化をグラフ化した。Fig. 13 のグラフは濃 茶、薄茶毎の各領域における入室時から退室時にかけての茶室の型 別の領域值の変化を示している。グラフ下には、茶事の流れを示し た。図下の表は客座毎の各領域における入室時、中間時、退室時の 最大、最小面積である。濃茶、薄茶の茶室の型に共通する個人領域 の領域值の特徵について分析すると、全ての型において入室時から 退室時にかけてほとんど変化がない。他人個人領域の領域値につい て分析すると、入室時から退室時の個人領域の領域值との差は、4 畳 半型濃茶 $0.54 \mathrm{~m}^{2}$ 薄茶 $0.48 \mathrm{~m}^{2} 、 4$ 畕半台目型濃茶 $0.21 \mathrm{~m}^{2}$ 薄茶 $0.34 \mathrm{~m}^{2}$ 、 その他濃茶 $0.67 \mathrm{~m}^{2}$ 薄茶 $0.66 \mathrm{~m}^{2}$ と入室時から退室時にかけて大きく なる (Fig. 13)。連帯領域の領域值について分析すると、概ね中間時 に領域值が一番大きくなり、退室時には中間時より小さくなる。こ れらから茶室の型の違いによる領域值の変化に差がないと考えられ る。次に濃茶と薄茶に共通する領域認知図の特徵について分析する
と (Fig. 14)、濃茶 Y 亭客座 1 や薄茶 Y 亭客座 4 のように、入室時の 形状に関係なく連帯領域は、退室時に全ての客座を包むようにつな がるようになることが明らかとなった。これは、空間要素に退室時 はお茶を飲んでいる人の空間はつながっているような感じがしたと 被験者が指摘しているように、お茶の種類に関係なく茶動作をとも にすることで客同士に親近感と一体感が生まれたため連帯領域がつ ながると考えられる。これらから茶室内における連帯領域は茶動作 に影響されるものであり、茶動作が一番多い中間時において最大に なり、動きが少なくなる退室時にかけて減少していくと考えられる。 しかし、空間要素に薄茶は会話ができるので客同士がつながるよう な感じがしたという被験者の指摘から、濃茶と薄茶では連帯領域の つながりが中間時に大きくなるという結果は同じでも、それぞれ理 由が違うと考えられる。客座毎に領域認知図の特徴についてみてい くと、連帯領域は薄茶 Y 亭客座 4 の様に亭主と客が個別につながる ような領域認知図が見られたように、これは一人一人にお茶を出す 薄茶の茶動作が影響したと考えられる。

\section{7. 領域認知に影響を及ぼす要素の比較}

領域認知図とともに空間要素を被験者に指摘してもらい、その指 摘率 (指摘数 / 被験者数、表示:\%) から空間要素を分析する (Fig. 15)。 濃茶、薄茶に共通している空間要素は、「採光」「畳」「音」といった 茶室の「建築要素」「お茶/菓子の受け渡し」「亭主の茶動作」「茶 事の流れ」「座っている位置/方向」「亭主の存在」「隣人 / 客」といっ た「茶動作要素」が指摘された。その他、「連帯感」や「緊張感」な ど「心理要素」が指摘され、これらの指摘は「建築要素」「茶動作要素」、 「心理要素」に分類できる。指摘は茶動作や茶室の人など「茶動作要素」 に関するものが特に多く、見慣れない茶動作に注目が集まりやすい 事や狭い茶室内において他人を意識する機会が多い事が確認できる。 「建築要素」の「採光」は、茶室内の明るい場所と暗い場所で自然に 領域が生まれていると考えられ、「畳」は、被験者が無意識に畳のへ リや畳割を、領域を区切る線と認識していると考えられる。濃茶、 薄茶の各要素の指摘率の差をみていくと、順に「茶動作要素」が $0.075 \%$ の差（以下略）（濃茶 $1.36 \%$ 薄茶 $1.29 \%$ 差 $0.075 \%$ 、以下濃 1.36 薄 1.29 差 0.075 )、「建築要素」が $0.015 \%$ 差（濃 0.50 薄 0.49 差 0.015 )、「心 理要素」0.020\%（濃 0.055 薄 0.035 差 0.020 ）となり、全ての要素に おいてほとんど同じで差がない。また濃茶、薄茶の指摘率においても、 全ての要素でほとんど指摘率が同じで差がない。一方、濃茶、薄茶 に共通して「茶動作要素」の指摘率がほかの要素に比べて高く、「お 茶／菓子の受け渡し」「亭主の茶動作」などの茶動作や「亭主の存在」 「隣人 / 客」などの茶室内の他人の存在が、濃茶、薄茶の違いに関係 なく被験者の空間要素に影響を及ぼすことがわかる。次に濃茶、薄 茶の指摘率で差が出た項目として順に、「お茶/菓子の受け渡し」が $0.25 \%$ （濃 0.46 薄 0.21 差 0.25 )、「会話」が $0.15 \%$ （濃 0.035 薄 0.18 差 0.15 ）、音」が $0.075 \%$ （濃 0.14 薄 0.065 差 0.075 )、「お茶や菓子 を食べる動作」が 0.060\%(濃 0.13 薄 0.19 差 0.060)、「座っている位置」 が 0.060\%（濃 0.080 薄 0.14 差 0.060）、「茶事の流れ」が 0.060\%（濃 0.12 薄 0.060 差 0.060 ）、盢」が $0.055 \%$ （濃 0.13 薄 0.075 差 0.055 ）、 「亭主の茶動作」が 0.05\%（濃 0.16 薄 0.11 差 0.050）の差となった。 これらの原因としては、濃茶を回し飲みするか、薄茶を 1 碗ずつ出 すかというお茶の飲み方の違いや、茶事での会話の有無といった濃 
茶、薄茶における茶動作の違いが大きく影響していると考えられる。 濃茶について分析すると、「お茶/菓子の受け渡し」が $0.46 \%$ と高く、 最も影響を及ぼす空間要素になっていることがわかる。次に「隣人、 客」が $0.17 \%$ 、「亭主の茶動作」「亭主の存在」が $0.16 \%$ 、「採光」、「音」、 「お茶や菓子を食べる動作」「畳」という順に空間要素であることが わかる。薄茶について分析すると、「お茶/菓子の受け渡し」が $0.21 \%$ と高く、最も影響を及ぼす空間要素になっていることがわかる。し かし、濃茶に比べ $0.25 \%$ 低い。これは濃茶はお茶と菓子を受け渡し するが、薄茶は菓子だけ受け渡しすることが原因と考えられる。次 に「お茶や菓子を食べる動作」が $0.19 \%$ 、「採光」、「隣人・客」、「会話」 が $0.18 \%$ 、「亭主の存在」「座っている位置」という順に空間要素で あることが明らかとなった。濃茶に比べ「会話」が $0.18 \%$ と高い数 值を示すのは、薄茶が終始会話することができるためと考えられる。 濃茶、薄茶の指摘率で差が出た項目の有意性については、「会話」「天 井の形状」「緊張感」「時間」「視線」の 5 つの要素において $5 \%$ 水準 で有意が確認された。有意差が確認された各要素と各要素の指摘率 の平均值についてみていくと、濃茶と薄茶の指摘率の平均值の差が 大きい「会話」は有意水準が小さい。「時間」「視線」は平均值の差 が小さく、有意水準が小さい。「天井の形状」「緊張感」は平均值の 差が小さく、有意水準が大きい。これらから、指摘率の差が大きい「会 話」が濃茶と薄茶の茶事や空間を評価することに影響に及ぼした要 素であることがわかる。

\section{8. 空間意識の構造}

$\mathrm{SD}$ 法心理実験（以下心理実験）は入室時と退室時で、心理実験 行った。これにより得られた被験者の評価値の平均值（以下心理量） を基に相関行列を求め、各尺度の因子負荷量及び固有值を求めた (Table1)。分析にあたっては、SPSS によるバリマックス法を用いた。 固有值 1 以上で分析の結果 8 軸あり、『広い一狭い』、『䨌囲気のある一 雾囲気のない』、『印象に残る一印象に残らない』、『明るい一暗い』 の 4 軸は複数の因子に負荷し、2つの負荷が絶対值 0.50 以上の尺度 について複合因子軸とし、4 軸の複合因子軸をを加え計 12 軸の心理 因子軸を決定した。また累積寄与率は、75.64 と比較的高い值を示し た。各因子の性質に対しそれぞれ分析を行なった（Tab1e2）。第一因 子は『緊張因子』と名付けた。『気楽な一息苦しい』尺度に代表され、 茶室内における気楽さなどを評価する。第二因子は『美的因子』と 名付けた。『質の良い一質の悪い』尺度に代表され、空間の質などの 值を評価する。第三因子は『変化性因子』と名付けた。これらの形 容詞対は、『変化のある一変化のない』尺度に代表され、茶事の流れ の変化などから来る意識を評価する。第四因子は『空間性因子』と 名付けた。これらの因子は『奥行きのある一奥行きのない』尺度に 代表され、茶事の歴史や空間の䨌囲気などを評価する。第五因子は 『立体性因子』と名付け、立体的な一平面的な』形容詞対に代表され、 茶室空間のプロポーションなどを評価する。第六因子は『特別性因子』 と名付けた。これらの形容詞対は『非日常的な一日常的な』に代表 され、茶室内においてお茶を飲むという行為など非日常性を評価す る。第七因子は『意匠性因子』と名付けた。これらの形容詞対は『派 手な一地味な』に代表され、茶室空間の印象、茶動作などを評価する。 以下、第八因子は『豊かさ因子』、複合因子として、『広い一狭い』、居 心地の良い一居心地の悪い』、『印象に残る一印象に残らない』、『明

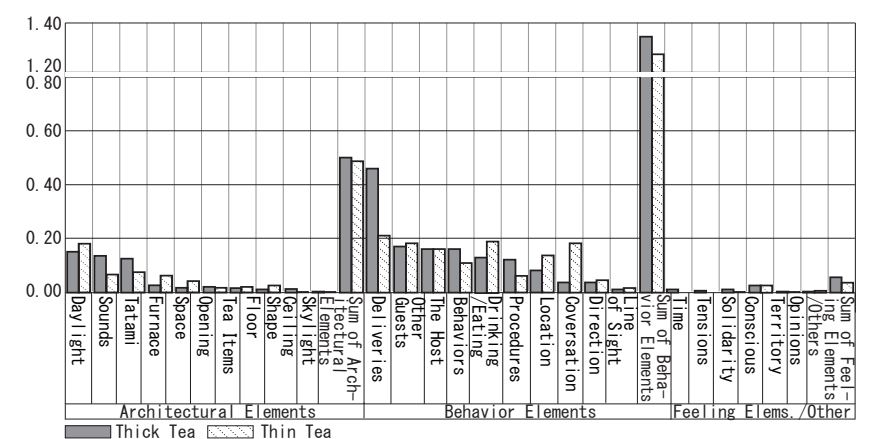

Fig. 15 Rates of factors that are pointed out affecting regional recognition

Table1 factor loading table

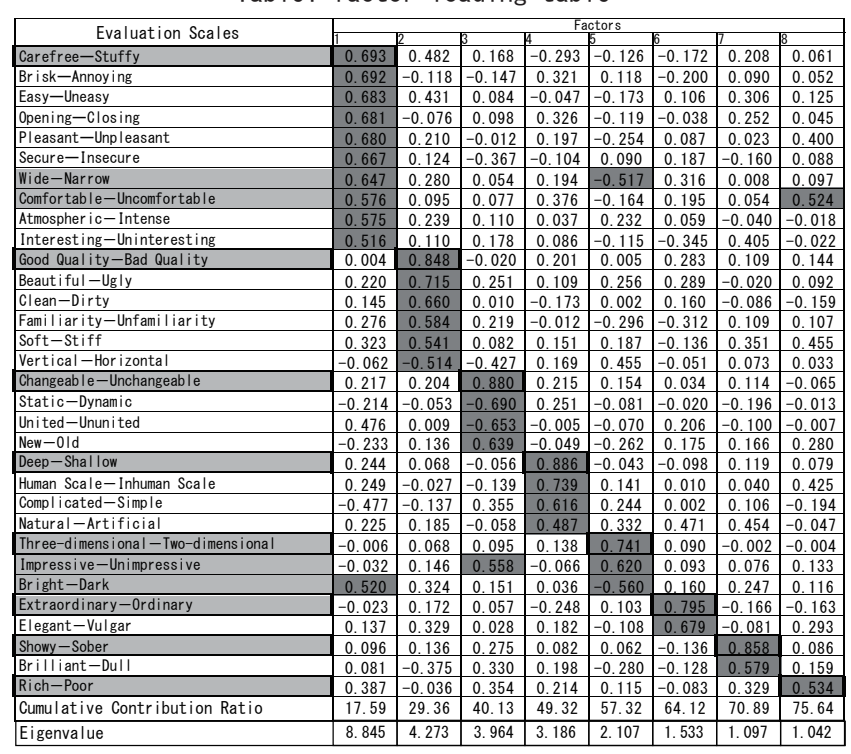

Table2 psychological factor axis table

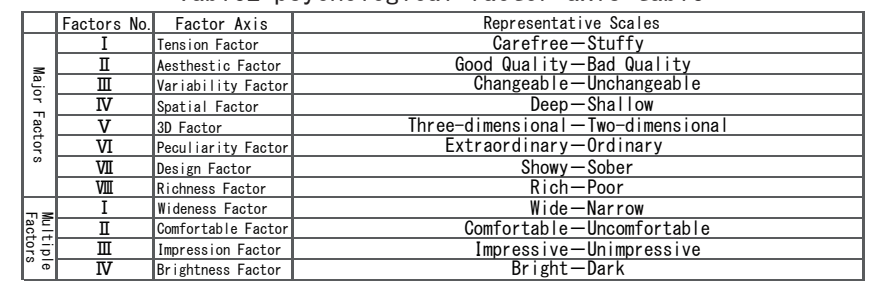

Average in Thick tea and Thin tea

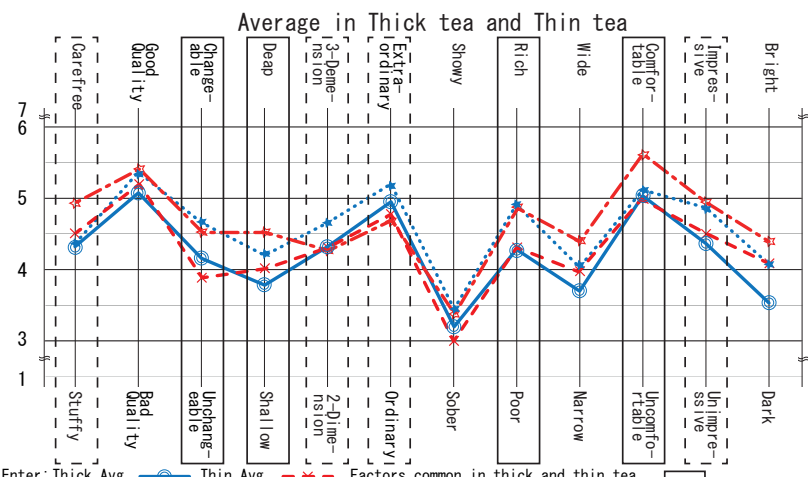

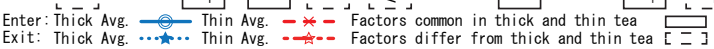

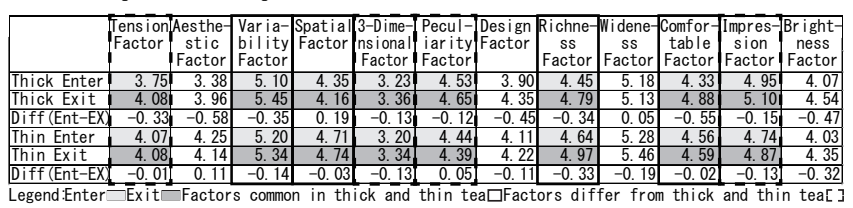

Fig. 16 Average changes among thick tea and thin tea yielded from SD experiment between entering and exiting the tea ceremony 
るいー暗い』を決定した。濃茶は、入室時から退室時にかけて「空 間性因子」、印象度因子」、「豊かさ因子」、「変化性因子」において $5 \%$ 水準で有意が確認された。薄茶は、入室時から退室時にかけて上記 濃茶のものに加え「緊張性因子」において $5 \%$ 水準で有意が確認され、 「印象度因子」に有意が確認されなかった。濃茶と薄茶の有意が確認 された因子の違いとして、薄茶は茶事の中で終始会話が出来ること で「緊張性因子」が被験者に気楽に感じさせたと考えることが出来、 濃茶は薄茶に比べ客座 1 が飲み終わるまで会話が出来なく、お茶を 回し飲み寸る茶動作が「印象度因子」の印象に残る感じの方向に変 化し、被験者に印象に残ると感じさせたと考えられる。

\section{9. 濃茶と薄茶における心理量分析}

濃茶、薄茶における入室時、退室時の平均の心理量 (以下心理量) の結果をもとに分析を行った (Fig. 16)。濃茶と薄茶の違いは、お茶 を飲屯行為は同じであるが、お茶が水分の少ないペースト状に対し 濃茶に比べ水分の多い泡状で、飲み方が 1 椀のお茶を客全員で回し 飲みするのに対し 1 人 1 碗ずつ飲むなど大きく異なる (Fig. 2)。その 条件下で濃茶と薄茶の共通して変化が見られた因子は、以下である。 空間性因子は入室時から退室時にかけて (以下略) 奥行きのある方 向に濃茶は 0.44 で薄茶は 0.50 に変化した（以下濃 0.44 薄 0.50 )、 変化性因子は変化のある方向に（濃 0.52 薄 0.61 )、豊かさ因子は豊 かな方向一(濃 0.65 薄 0.53 )、印象度因子は印象に残る方向に(濃 0.47 薄 0.41 ) 変化が見られた。それらを考察すると、濃茶と薄茶は、お 茶の飲み方やお菓子の種類の違いはあるものの、亭主が茶室に入り 茶動作が行われ退室するまで、亭主や客の茶動作が茶室内全体にわ たり行われることで客同士の連帯感が高まり、連帯領域が濃茶は 0.5 $\mathrm{m}^{2}$ 程度、薄茶は $0.35 \mathrm{~m}^{2}$ 程度大きくなるため (Fig. 16)、客に奥行きが あると感じさせたと考えられる。次に変化性因子は、茶室内におい て茶事の初めの静的な䨌囲気から動的な茶動作の体験と時間を経て、 客に変化を感じさせたと考えられる。また、豊かさ因子は茶室にお いて亭主のおごそかな茶動作などで、客に豊かさを感じさせたと考 えられる。さらに、印象度因子は普段体験することの少ない客が茶 室において茶事を体験し、自ら茶動作を行うことで、客に印象に残 ると感じさせたと考えられる。一方濃茶と薄茶で違いが見られる心 理量は、快適性因子、緊張因子、特別性因子である。濃茶に比心゙薄 茶の変化量が大きく見られた因子は以下である。快適性因子は居心 地の良い方向に濃茶は 0.10 で、薄茶は 0.64 となり差は 0.54 であっ た。(以下濃 0.10 薄 0.64 差 0.54)、緊張因子は気楽な方向に(濃 0.030 薄 0.41 差 0.38)、特別性因子は日常的な方向に（濃 -0.23 薄 0.070 差 0.30) 変化が見られた。薄茶は、濃茶と違い茶事の中で亭主や客 同士と終始会話ができることや、ゆったりとした雰囲気で行われる ため窮屈には感じず、快適性因子は客に居心地の良いと感じさせた と考えられる。次に濃茶は、客座 1 が飲み終わるまで無言の中で茶 事が進むが、薄茶は濃茶の後のゆったりとした䨌囲気で茶事が進み、 亭主や客同士と会話がある中で 1 人 1 椀のお茶が客に出されるため、 緊張因子は客に気楽に感じさせたと考えられる。また薄茶では、ペー ス卜状の鍊られたお茶ではなく、見慣れた泡状の点てられたお茶が 飲めることや会話のあるゆったりとした䨌囲気の中で行われるため、 特別性因子は客に日常的と感じさせたと考えられる。

\section{0 .まとめ}

各茶室の実地調査における領域認知図、茶事や空間を評価するこ とに影響を及ぼした要素、心理量を分析することで領域認知と、空 間意識の特徴の一端を明らかにした。

1. 領域認知図の分析より、個人領域は、入室時から退室時にかけ てほとんど変化しない。しかし、他人個人領域は入室時から退室 時にかけて増加する。連帯領域は、茶動作が一番多い中間時におい て増加し、動きが少なくなる退室時にかけて減少していく。濃茶の 連帯領域の変化量は、薄茶より大きい。空いている空間が隣接する 場合は、空いている空間に個人領域が広がる。 茶室の型で共通する領域の特徴は、

領域認知図の分析より、

(1)濃茶は、退室時に連帯領域が客全員でつながる。

(2)薄茶は、どのタイミングでも会話している隣同士と連帯領域がつ ながる。

(3)濃茶、薄茶それぞれにおいて連帯領域のつながり方は、茶室の型 による違いはない。

領域值の分析より、

(1)個人領域の濃茶、薄茶における入室時から退室時の領域值の変化 は、ほとんどない。

(2)他人個人領域の濃茶、薄茶における領域値の変化は、入室時より 退室時が大きくなる。

(3)連帯領域の濃茶、薄茶における共通する領域值の概ねの変化は、 中間時に領域值が一番大きくなり、退室時は中間時より小さくなる。 茶室の平面の違いで共通する領域の広がりの特徴は、

領域認知図の客座の分析により、濃茶、薄茶ともに被験者のまわり の空いている空間が隣接する場合、個人領域がその空間に広がる。

2. 指摘要素の分析より空間要素は、濃茶、薄茶ともに「茶や菓子 の受け渡し」である。茶事の流れや茶動作により濃茶のほうが高い 指摘率を示す。

3. 心理量の分析より濃茶と薄茶において入室時から退室時にかけ て共通して変化する心理量は、空間性因子、変化性因子、豊かさ因 子、印象度因子である。共通する心理量の変化は、濃茶と薄茶共通 の茶事の流れと被験者同士の連帯感が関係寸る。一方、差が確認で きる心理量は、快適性因子、緊張因子、特別性因子である。これらは、 会話の有無や回し飲みか個別かの飲み方の差による影響が大きい。

今回の調查で、茶事を通して濃茶、薄茶ともに空間性因子、豊か さ因子、印象度因子の心理量が入室時から退室時にかけて大きくな ることで、被験者同士の連帯感が高まり連帯領域の領域值が大きく なることがわかった。連帯領域の領域值は、お菓子を取り回寸茶動 作を客同士で共有する中間時に一番大きくなる。濃茶、薄茶ともに 茶室の型の違いにより、個人領域の変化の仕方に差がでることがわ かった。

今後は、領域認知と心理量の相関分析や数量化分析の考察を行う。 また濃茶、薄茶だけではなく、初座席入より炭点前、懷石について 調査する予定である。

\section{参考文献}

1) Yuta ITo, Kengo KUMA, Ko NAKAMURA: THE STUdY OF THE ARCHITECTURAL STYLE OF TEA HOUSE BY THE MULTIVARIATE ANALYSIS USING THE DATA OF THE PRESENCE OR ABSENCE OF ELEMENTS -The 
study of the morphological composition of Japanese tea house, part1, Journal of Architecture and Planning(Transacions of AIJ), Vol. 80 No. 716, pp. 2365-2373, 2015. 10

伊藤雄太, 隈研吾, 中村航: 構成要素の有無に着目した多変量解析に よる茶室意匠様式の分析 茶室の携带構成に関する基礎的研究その 1 , 日本建築学会計画系論文集, 第 80 巻, 第 716 号, pp. 2365-2373, 2015. 10

2) Yuta IT0, Kengo KUMA, Ko NAKAMURA: THE STUdY OF THE ARCHITECTURAL STYLE OF "SOAN" TEA HOUSE THROUgh THE MULTIVARIATE ANALYSES OF THE PHYSICAL QUANTITATIVE DATA OF ELEMENTS The study of the morphological composition of Japanese tea house. part2, Journal of Architecture and Planning(Transacions of AIJ), Vol. 81 No. 724, pp.1411-1419, 2016.6

伊藤雄太, 隈研吾, 中村航: 構成要素の物質量に着目した多変量解 析による草庵茶室意匠様式の分析 茶室の携带構成に関する基礎的研 究その 2, 日本建築学会計画系論文集, 第 81 巻, 第 724 号, pp.14111419, 2016. 6

3) Yasuko KOND0, Yoshitsuna KUTSUKI and Waro KISHI: SUTEMI HORIGUCHI'S ARCHITECTURAL THOUGHT- An inquiry into the theory of creation in his study of the tea ceremony-, Journal of Architecture and Planning(Transacions of AIJ), Vol. 76 No. 665, pp. $1329-1336,2011.7$

近藤康子, 朽木順綱, 岸和郎：堀口捨己の建築思想に関する研究 - 茶 の湯研究に見出される制作の問題 -, 日本建築学会計画系論文集, 第 76 巻第 665 号, pp. 1329-1336, 2011.7

4) Yasuko KONDO: A STUdY ON THE MEANING OF "CHARCOALCONSTRUCTION" IN HORIGUCHI SUTEMI'S ARCHITECTURAL THOUGHT, Journal of Architecture and Planning(Transacions of AIJ), Vol. 79 No. 703 , pp. 2059-2065, 2014. 9

近藤康子：堀口捨己の建築思想における「炭組み」について, 日本建 築学会計画系論文集, 第 79 巻, 第 703 号, pp. 2059-2065, 2014.9

5 ) Yasuko KONDO: A STUdy ON THE MEANING OF "CENTER-POST" IN HORIGUCHI SUTEMI'S ARCHITECTURAL THOUGHT, Journal of Architecture and Planning (Transacions of AIJ). Vol.82 No.738, pp. 2105-2112, 2017.8

近藤康子：堀口捨己の建築思想における中柱の意味, 日本建築学会計 画系論文集，第 82 巻，第 738 号, pp. 2105-2112, 2017.8

6 ) Keiko NAGATA: IMPORTANCE AND CHARACTERISTIC OF UTENSILS FOR TEA CEREMONY IN JAPANESE TRADITIONAL FURNITURE REFERENCE BOOKS CONCEPT OF ARCHITECTURE, Journal of Architecture and Planning(Transacions of AIJ), Vol.76 No.668, pp. 1937-1942, 2011. 10

永田恵子 : 建築書系道具佯形における茶の道具の重要性と記述の特質, 日本建築学会計画系論文集, 第 76巻, 第 668 号, pp. 1937-1942, 2011. 10

7 ) Asae OZAWA: THE STUDY ON THE 'OCHA-YA' IN IMADEWA PALACE OF KATSURANO-MIYA HOUSE HOLD, Journal of Architecture, Planning and Environmental Engineering (Transacions of AIJ), No.463, pp. 175-182, 1994. 9

小沢朝江 : 桂離宮の今出川屋敷における御茶屋について - その沿革・ 特色・使い方と桂離宮など洛外の別荘との比較 -, 日本建築学会計画系 論文集，第 463 号 ,pp. 175-182, 1994. 9

8) Sadaaki OGISO, Kohichi SUGIMOTO: REPORT ON LIGHTING OF THE CEREMONIAL TEA-ROOM(1), Transactions of the Architectural Institute of Japan, No. 230, pp. 99-108, p. 112, 1975. 4 小木曾定彰, 杉本幸一; 茶室の採光に関する研究 (1), 日本建築学会論 文報告集，第 230 号, pp. 99-108, p. 112, 1975.4

9) Sadaaki OGISO, Kohichi SUGIMOTO: REPORT ON LIGHTING OF THE CEREMONIAL TEA-ROOM(2), Transactions of the Architectural Institute of Japan, No.231, pp. 89-93, p. 99, 1975.5 小木曽定彰, 杉本幸一: 茶室の採光に関する研究 (2), 日本建築学会論 文報告集，第 231 号, pp. 89-93, p. 99, 1975.5

10 ) Keisuke KITAGAWA, Junko YOKOYAMA, Yukihiko HAYASE, Kazuyoshi FUMOTO and Shigeru WAKAYAMATHE: THE COMPOSITION OF VISIBILITY ON THE POSITION OF HOST AND MAIN GUEST IN THE TEA ROOM-A study on architectural plan description and evaluation with "sight depth", Journal of Architecture, Planning and Environmental Engineering (Transacions of AIJ), No. 541, pp. 115-122, 2001, 3
北川啓介, 横山順子, 早瀬幸彦, 麓和善, 若山滋 : 茶室内の亭主位置 と正客位置における視空間の構成についてーく視深度〉による建築平 面記述・評価の研究, 日本建築学会計画系論文集, 第 541 号, pp.115122, 2001. 3

11 ) Yuuki NAKAMURA, Shigeyuki OKAZAKI and Toshitomo SUZUKI: FIXATION BEHAVIOR IN WALKING ON TOBIISHI IN ROJI, THE GARDEN OF TEA CEREMONY ROOM, Journal of Architecture, Planning and Environmental Engineering (Transacions of AIJ), No.560, pp. 151-158, 2002.10

中村祐記，岡崎甚幸，鈴木利友：茶室露地における飛石歩行の際の注 視行動, 日本建築学会計画系論文集, 第 560 号, pp. 151-158, 2002. 10

12 ) Yusuke SAT0 and Kiyoshi SHINGU: PROPOSAL OF A DISCRIMINATION METHOD OF COMPOSITION IN CHASHITSU DESIGN, Journal of Architecture and Planning(Transacions of AIJ), No. 589, pp. 221$227,2005.3$

佐藤祐介, 新宮清志 : 茶室意匠におけるコンポジション認識の手法の 提案, 日本建築学会計画系論文集, 第 589 号, pp. 221-227, 2005.3

13 ) Chika GOTO, Yoshiko HIROKAWA, Tetsuo SEGUCHI: A STUDY ON THE SUCCESSION TO THE DESIGN OF THE TEA-CEREMONY ROOM BY "UTSUSHI" -A case of Tai-an in Myoki-an-, Journal of Architecture and Planning(Transacions of AIJ), Vol.73, No. 633, pp. 2475-2482, 2008. 11

後藤千夏, 廣川美子, 瀬口哲夫 :〈写し〉による茶室の継承に関する研 究一妙喜庵茶室待庵を事例として, 日本建築学会計画系論文集, 第 73 巻, 第 633 号, 2475-2482, 2008. 11

14 ) Chika Goto, Tetsuo SEguCHIA: STUdy ON SUCCESSION AND ORIGINALITY OF MODERN TAIAN UTSUSHI - Rikyu' s idea of the tea ceremony and features of the tea ceremony room-, Journal of Architecture and Planning(Transactions of AIJ), Vol. 75 No. 654 , pp. $1855-1863,2010.8$

後藤千夏, 瀬口哲夫 : 近現代の待庵の写し茶室における継承と創意に 関する研究 利休の茶の精神と茶室の造形的特徵, 日本建築学会計画系 論文集，第 75 巻，第 654 号, pp. 1855-1863, 2010.8

15 ) Makoto MiZuTAni, Keisuke Kitagawa, Nobumichi KANAmori, Kauyoshi and Shigeru WAKAYAMA: "SPACE ENCLOSURE" IN TEA ROOM IN CONSIDERATION OF “SIGHT-DEPTH", Journal of Architecture and Planning(Transacions of AIJ), Vol.76 No.667, pp. 1559-1567, 2011.9

水谷誠, 北川啓介, 金森信道, 麓和善, 若山滋 : 視深度 >から見る 茶室の内部空間の〈空間包囲性〉, 日本建築学会計画系論文集, 第 76 巻, 第 667 号, pp. 1559-1567, 2011.9

16 ) Takao AKAGAWA, Aya NAGA0: Research on spatial analysis of Teahouse space by "Saho" sequence, Transaction of the AIJ Kyushu, pp. 677-680, 2010.3

赤川 貴雄, 永尾 彩 : 茶室空間の”作法”動線による空間分析に関す る研究, 日本建築学会研究報告, 九州支部, 3, 計画系 (49), pp. 677-680, 2010.3

17 ) Tohru FUNAKOSHI, Tsumita HIROSHI, Masahiko HASHIMOTO, Yumiko YAMADA, Toshiaki IIMURA:SHOINDUKURI SPACE ANALYSIS OF SHOIN AND TEA CEREMONY R00M No. $1 \sim$ No.8, Summaries of Technical Papers of Annual Meeting, Architecural Institute of Japan, pp. 829-836, 1981.7

船越徹, 積田洋, 橋下雅彦, 山田由美子, 飯村俊章 : 書院造・茶室 の空間分析, その $1 \sim 8$, 日本建築学会大会学術講演梗概集, 計画 系, pp. 829-836, 1981.7

18 ) Kuniko HASHIMOTO, Kazuhiko NISHIDE, Kimiko TAKAHASHI, Takashi TAKAHASHI: A STUDY ON THE PSYCHOLOGICAL TERRITORY BASED ON EXPERIMENTS OF INTERPERSONAL HORIZONTAL DISTANCE, Journal of Architecture, Planning and Environmental Engineering (Transactions of AIJ), No. 485, pp. 135-142, 1996. 7

橋本都子, 西出和彦, 高橋公子, 高橋鷹志: 実験による対人距離から みた心理的領域の平面方向の拡がりに関する考察, 日本建築学会計画 系論文集，第 485 号, pp. 135-142, 1996.7

19 ) Tetsuro KARIYA, Kazuhiko NISHIDE, Takashi TAKAHASHI: SOLID ANGLE RATIO AND AFFECTIVE MEANING WHICH CONSTRUCT PERSONAL SPACES - Studies on personal spaces constructed by informations Part 1, Journal of Architecture and Planning 
(Transactions of AIJ), No. 613, pp. 127-134, 2007.3 䒵谷哲朗, 西出和彦, 高橋鷹志 : パーソナル・スペースを構築する 立体角比と情緒的意味に関する考察：構築情報によるパーソナル・ スペースに関する研究 その1, 日本建築学会計画系論文集, 第 613 号, pp. 127-134, 2007.3

20 ) Yumi FUKUDA, Ken MORITA: THE EFFECT OF AN INTRUDER ON PERSONAL SPACE WITH REFERENCE DOMAINS OF DEMONSTRATIVE PRONOUNS AND PHYSIOLOGICAL RESPONSES, AIJ Journal of Technology and Design, No. 15 , pp. $195-198,2002.6$

福田裕美, 森田健：パーソナルスペースへの他人の侵入がもたら 寸指示領域及び生理面への影響, 日本建築学会技術報告集, 第 15 号, pp. 195-198, 2002.6

21 ) Daisuke HANYU, Kazuto HAYASHIDA, Satoru HAIBARA, Hitoshi WATANABE: 5010 Taijinjoukyoukaniokerushiseiniyorupāsonarusup ēsunosousanikansurukenkyuu - Seishinseihakkanryoukeisokuniyo rukankakunoteiryouka(Kenchikukeikaku), Transaction of the AIJ Kanto, Vol.2, No. 75, pp. 37-40, 2005.2

羽生大輔，林田和人，生原悟，渡辺仁史 : 5010 対人状況下における姿 勢によるパーソナルスペースの操作に関する研究 精神性発汗量計測に よる感覚の定量化 (建築計画), 日本建築学会研究報告, 関東支部, 研 究報告集 II, 第 75 号, pp. 37-40,2005.2

22 ) Ataru SHI0, Hiroki SUZukI: STUdy ON CHANGE AND SPACE EVALUATION OF THE PERSONAL SPACE WITH THE TEA BEHAVIOR IN THE TEA-CEREMONY ROOM No. $1 \sim$ No. 5, Summaries of Technical Papers of Annual Meeting, Architecural Institute of Japan, Architectural Planing and Design,pp. 799-800, 2017.7

子浦中，鈴木弘樹：茶動作に伴うパーソナルスペースの変化と空間 評価の予備実験 - 茶室空間における茶動作に伴うパーソナルスペー スの研究その $1 \sim 5$, 日本建築学会大会学術講演梗概集, 建築計 画, pp. 799-800, 2017.7

23 ) Masao NAKAMURA: Cashuotokennchiku (Tea master and architecture) , Kashimashuppannkai , 1971 中村昌生 : 茶匠と建築, 鹿島出版界, 1971

24 ) Terunobu FUJIMORI: Fujimoriterunobunochashitugaku Nihonnno gokushoukuukannnonazo(Terunobu Fujimori's Tearoom Study-The mystery of the smallest space in Japan), X Knowledge Inc., 2012 (in Japanese)

藤森照信 : 藤森照信の茶室学, 日本の極小空間の謎, 株式会社エクス ナレッジ,2012 (in Japanese)

25 ) Masao NAKAMURA: Nakamuramasaogakatarukennchikukouza Kotennni manabukennchikukouza (Architecture lecture by Masao Nakamura, Architecture lecture to learn from the classics), Chuo Seihan Printing corporation, 2013 (in Japanese)

中村昌生 : 中村昌夫が語る建築講座 古典に学ぶ建築講座, 中央精版印 刷株式会社, 2013

26 ) SHOKOKUSHA Publishing Co., Ltd. : Kennchikudaijitenndainiha nn<Hukyuban〉 (Architectural Dictionary 2nd Edition<popular version>), April, 1997.4 (in Japanese)

株式会社彰国社：建築大辞典第 2 版〈普及版〉, 株式会社彰国 社, 1997. 4

27 ) TANKOSHA: Sadoujiten(Tea ceremony dictionary), 1979.9 (in Japanese)

株式会社淡交社：茶道辞典，株式会社淡交社, 1979.9

28 ) Architectural Institute of Japan: Kenchiku-Toshikeikakunotame nokuukanngakujitenn(Spatial encyclopedia for architecture and urban planning) - INOUE SHOIN CO., LTD, 2016 (in Japanese) 一般社団法人日本建築学会編：建築・都市計画のための空間学事典 [増 補改訂版］，井上書院，2016

\section{注}

注 1 ） 茶室は茶湯に使う建物をいう。単に座敷だけを指す場合もあり、ま た付属施設及び露地を含めて使うこともある。

注 2 ) 茶湯は、茶湯芸能のこと。中世の茶数寄と同じ。近世以降は茶道に 対する和称あるいは雅称として用いられている。

注 3 ）千利休は茶人にして和泉堺の豪商。名は与次郎、法諱は宗易、利休 は居士号。北向道陳・武野紹鴎に茶を学び、信長と秀吉の茶頭を務 める。草庵茶室の創始者で、また初めて数寄屋普請を試みる。茶道
具、茶室、茶庭などにおいて独創的なデザインを行った。䠰口、飛石、 庭園の石灯籠などは彼の創意による。秀吉の命で自刃。

注 4 ) 村田珠光は茶匠。奈良称名寺の僧。一休宗純の下に参禅。将軍足利 義政に仕えたというが不明。茶の湯専用の茶室として 4 盢半を創始。 子は宗珠で、下京に住して侘びの庭を構えた。

注 5 ）草庵茶室は四畳半以下の小間の茶室。草莫き民家を洗練させた形式 を持ち、千利休によって大成された。ここで行われる喫茶の礼や会 席料理は、書院式茶室のそれとは異なる。

注 6 ）茶事は茶会のこと。正午の茶事を正式とし、茶事七式のほか一客一 亭の茶事、名残の茶事、口切の茶事などがある。

注 7 ） 今回は調査として統一した条件とするため、外部は見えないように 障子や襖は閉め室内のみの調査を行っている。また、亭主に近い位 置から正客が座ることに統一して調査しており、風炉や炉によって 着座位置は変えないことを統一条件とした。

注 8 ）被験者を過去に調査に使用した茶室を訪れたことがないことを条件 とした理由は、慣れなどが今回の調査の評価に影響しないように、 茶室や茶事に対する先入観がなく、過去に調査に使用した茶室を訪 れたことや茶事を体験したことのないこととしたためである。また、 領域認知実験において認識した領域をより正確に図で表現してもら う必要があるため、被験者は建築を専攻する学生とした。

注 9 ) 織田有楽の如庵は、2 畳半台目で 3 畳の少し変形で半畳に 1 人座る ことができるため、本研究では 3 畳から 4 畳半までを研究対象とした。 如庵に近い茶室をデータとして組み込むためC-An を選んだ。C-An は茶室の形により半畳に 1 人座ることから少し外れるため、大きさ の異なる茶室で半畳に 1 人ずつ座ることを目安とする条件とした。

注 10 ） SD 法心理実験は、実験の対象となる空間を体験させ、複数の形容詞 句対による言語尺度から評価值を得る心理的評価実験方法。空間研 究では空間が人に与える心理的評価の影響を定量的に得るために使 われる。

注 11 ）本研究の「領域認知」は、これまでの「空間認知」の研究を参考に しつつ、茶室内において茶事の流れとともに変化する個人の頭の中 にある個人領域や他人個人領域、連带領域のイメージを捉えること である。そのため本研究における領域認知図は、茶事中に床面に広 がる個人領域や他人個人領域、連带領域を茶事を体験した後に記憶 を想起し図化したものとする。 


\title{
STUDY ON RECOGNIZED SPACE ON PLANE SURFACE AND PSYCHOLOGICAL EVALUATION IN THE TEA CEREMONY ROOM
}

\author{
Ataru SHIO ${ }^{* 1}$ and Hiroki SUZUKI*2 \\ ${ }^{* 1}$ Grad. Student, Dept. of Architecture, Faculty of Science and Engineering, Chiba Univ., M.Eng. \\ ${ }^{*}$ Assoc. Prof., Dept. of Architecture, Faculty of Engineering, Chiba Univ., Dr.Eng.
}

Tea ceremony room is the architecture built for tea ceremony. Because of the awareness of the floor surface by the host and guests, we focus on the spatial region that a guest recognizes as the space of his own, space of other guests and solidarity space, we define this spatial region as the region. In this research, we try to clarify the changes and characteristics on the region of guests and the host and the one shared by guests during a tea ceremony.

We defined that when an individual is situated in tea ceremony room, the region that can be considered as belong to that individual as “personal space” , the regions around other guests as “other's personal spaces" and regions with solidarity as "solidarity space". We hypothesize that these kinds of region will be changed during thick tea and thin tea with certain relationship. We also defined that personal space, other s personal space and solidarity space as "regional recognition". In this research, to clarify the changes of regional cognition and the ways space is felt, the field research below is commenced. 1. SD(semantic differentiation) method psychological experiment to figuring out what cognition would tea ceremony and space would provide to guests. 2. Regional cognition experiment to figuring out the changes of personal space, other' s personal space and solidarity space, also the tendency of reginal cognition. 3 . Testees are also asked to write down the items that influenced the evaluations of tea ceremony and the space. By analyzing the regional cognition diagram, the evaluation of tea ceremony and the space, and the psychological quantities, some characteristics of territorial cognition and spatial consciousness were clarified. During the tea ceremony, spatial factor, richness factor and impression factor become larger from enter to exit in both thick tea and thin tea, at the same time the solidarity space enlarged indicating the rise of feeling of solidarity. The area of solidarity space becomes biggest in the middle time when the tea behavior of passing the dessert among guests happens. The personal space tends to expand to the space that unoccupied by the different types of tea ceremony room in both thick tea and thin tea. 1). The common characteristics in different types of tea ceremony are 1 isted below: According to regional cognition diagram, in thick tea, the solidarity space tends to connect to all guests in exit time. In thin tea, no limitation for conversation influencing the solidarity space connect to the guests who are neighbor to each other. The ways of connection of solidarity space are different in different type of tea ceremony room in both thick tea and thin tea. According to the area of region, the personal space stays almost unchanged from enter to exit time in both thick tea and thin tea. Other' s personal space becomes bigger at exit than enter time in both thick tea and thin tea. Solidarity space becomes biggest at middle and smaller at exit comparing with middle approximately. 2). The most influential factor in territory recognition is "delivery of tea and sweets" for both thick and thin tea. 3). The common psychological factors that change simultaneously among thick tea and thin tea, are spatial factor, variability factor, richness factor and impression factor, while comfortable factor, tension factor and peculiarity factor change differently. 